\title{
Protean and boundaryless career attitudes scale: Spanish translation and validation
}

\author{
Mihaela Enache ${ }^{1}$, Inés González ${ }^{2}$, David Castillo ${ }^{2}$, Oriol Lordan ${ }^{1}$ \\ ${ }^{1}$ Universitat Politècnica de Catalunya, ${ }^{2}$ Universitat Oberta de Catalunya (Spain) \\ Mihaela.enache@upc.edu, igonzalezgonzalez@uoc.edu,dcastillo@uoc.edu, \\ oriol.Iordan@upc.edu
}

Received November, 2011

Accepted April, 2012

\section{Abstract}

Purpose: The aim of this paper is to translate into Spanish and examine the psychometric properties of the resulting Spanish version of Briscoe, Hall and DeMuth (2006)'s Protean and Boundayless Career Attitude Scale, encompassing: Self-Direction, Values-driven predispositions, Boundaryless mindset and Organizational Mobility Preference.

Design/methodology/approach: Translation of the Protean and Boundayless Career Attitude Scale was carried out using a back-translation procedure and cognitive interviews were conducted to ensure an accurate interpretation of questionnaire items. The validity and reliability of the scale were evaluated using exploratory factor analysis and Cronbach's alpha coefficients. Finally, confirmatory factor analysis was performed to evaluate the factor structure of the modified version of the scale, which consists in those items with higher factor loadings.

Findings: The reliability coefficients of the modified scale are consistent with those reported by Briscoe et al. (2006). Nevertheless, the values-driven attitudes scale seem to measure two latent traits: strong core beliefs regarding one's definition of career success and individual emphasis of core 
personal values through work (reliance on personal values when individual and organizational values do not match).

Originality/value: This is the first study which provides a Spanish translation of the Protean and Boundaryless Career Attitude Scale.

Keywords: protean, boundaryless career attitudes scale, translation, Spanish

Jel Codes: M19, D23

\section{Introduction}

Nowadays, the extant literature recognizes that traditional orderly and hierarchical careers are increasingly losing ground to new career conceptualizations, such as boundaryless and protean perspectives, which better capture the realities of a changing scenario. Researchers argue that in response to substantial changes induced by today's knowledge driven context - globalization, increasing competitive pressures, democratization of work life (Gratton \& Ghoshal, 2003), alterations of the psychological contract (Rousseau, 1989), decrease in job security (Cappelli, 1999) and increasing reliance on the dissemination and application on intellectual capabilities (Powell \& Snellman, 2004) for creating and sustaining competitive advantages - careers become more boundaryless (Arthur \& Rousseau, 1996) and individuals develop protean mindsets (Hall, 1976, 2002, 2004) for successfully navigating the current business scenario. These two perspectives suggest that the individuals become the sculptors of their own careers (Bell \& Staw, 1989), which are less bounded to a single employment setting (Arthur \& Rousseau, 1996).

The study of protean and boundaryless careers is relevant in psychological research because these new career perspectives have been associated with, among other aspects: subjective career success (Enache, Sallan, Simo \& Fernandez, 2011), organizational commitment (Fernandez \& Enache, 2008; Briscoe \& Finkelstein, 2009) and employability (McArdle, Waters, Briscoe \& Hall, 2007). Therefore, it is crucial to have instruments to assess boundaryless and protean career attitudes adapted to our environment and with adequate psychometric properties. In that sense, the aim of this research is to translate into Spanish and to analyse the psychometric properties of protean and boundaryless career attitudes scales, focussed on a sample of 150 professionals attending graduate and post-graduate distance-learning courses. 


\section{Theoretical framework}

Briscoe et al. (2006) developed protean and boundaryless career scales to operationalize the concept of protean (Hall, 1976, 2002) and boundaryless (Arthur, 1994) career. A boundaryless career highlights an independent, individually driven and subjectively addressed career concept (Arthur \& Rousseau, 1996). The boundaryless career focuses on career enactment (Weick, 1996) and has been defined as "a sequence of job opportunities that goes beyond the boundaries of a single employment setting" (DeFillippi \& Arthur, 1994: p307), capturing career moves crossing physical and psychological dimensions (Briscoe et al., 2006; Sullivan \& Arthur, 2006). Arthur and Rousseau (1996) identified six different meanings of the boundaryless career, arguing that it is a complex concept that, apart from emphasizing inter and intra-organizational mobility, encompasses careers that can be extrapolated to employees' perceptions of the desirability or instrumentality of increased mobility (Feldman \& Ng, 2007). Whereas some authors have approached boundaryless careers uniquely considering physical changes in work arrangements (Jones, 1996; Saxenian, 1996), Sullivan and Arthur (2006) emphasize the need of viewing mobility as measured along two continua (physical and psychological), in order to bring greater precision to research endeavours. In an extensive review of the empirical research conducted on the changing nature of careers, Sullivan (1999) asserted that "only sixteen studies examined mobility across physical boundaries, whereas only three studies focused on the relationships across these boundaries" (Sullivan \& Arthur, 2006). Recognizing that a boundaryless career attitude is primarily psychological, Briscoe et al. (2006) provided empirical evidence, supporting for the development of two boundaryless career attitudes: boundaryless mindset and organizational mobility preference.

Briscoe et al. (2006) defined a boundaryless mindset as an opening-up attitude to the world, asserting that "a person with a high boundaryless attitude towards working relationships across organizational boundaries is comfortable, even enthusiastic about creating and sustaining active relationships beyond organizational boundaries". It refers to a general attitude of transcending organizational boundaries, by feeling comfortable in interacting with people from different organizations and seeking out opportunities for experiencing new situations that result beneficial for the individual (e.g. providing the opportunity to enhance knowledge and skills). Organizational mobility preference, on the other hand, refers to individuals' tendency towards organizational embeddedness (Briscoe et al., 2006). Thus, it is concerned with one's preference for job security, predictability and long-term employment. 
Researchers and practitioners argued that in the context of a boundaryless career, individuals develop a specific mindset or approach, called protean orientation, for successfully navigating the current unstable organizational context (Hall, 1976, 2002; Hall, 2004). The term "protean" derives from the Greek god Proteus who had the uncanny ability to change his shape at will in order to avoid oncoming threats. Within the context of a protean career, individuals, rather than their employing organizations, become the architects of their own career, development and vocational destiny. This orientation represents an internally driven and self-directed perspective in managing one's career that reflects values such as freedom and adaptability (Hall, 1976, 2002). Baruch (2004: p71) described the protean career as: "a contract with oneself, rather than with the organization", as individuals "take responsibility for transforming their career path, in taking responsibility for their career".

Rather than simply responding to their changing environment, these career actors are in charge of and responsible for creating their own careers paths. As Hall (2004) and Hall and Chandler (2005) remarked, the hallmarks of a protean orientation are: freedom and growth, professional commitment, and the attainment of psychological success, through the pursuit of meaningful work and the discovery of a "calling". Protean careers combine individual qualities of strong sense of identity and high adaptability to fit new situations (Hall, 2002). The adaptability factor is clearly important in today's rapidly-changing career conditions, while the identity factor provides an anchor or "compass" such as occupation or industry may give the individual a sense of a secure base. The contracting out of work often enables people to keep an occupational or even organizational identity, while adapting substantially in the way they organize their work and careers (Peel \& Inkson, 2004).

Briscoe et al. (2006) identified two protean-career relevant attitudes - self-directed career attitudes and values-driven predispositions, and developed new scales for measuring them. According to the authors, self-direction is characterized by selfreliance in making career plans and decisions and proactivity in willingness to seek out change and take actions. In other words, individuals rely on themselves in making career decisions and actively take the initiative in gathering information, developing goals, and making decisions, rather than waiting for others, especially the organization, to provide information, feedback, goals, and plans. On the other hand, values-driven makes reference to individual's reliance upon a personal definition of career success and emphasis upon fulfilling personal values through work. More specifically, an individual with a protean orientation pursues work 
experiences that are personally meaningful to the individual, rather than pursuing experiences that make sense to other entities (family, friends, and the organization). Moreover, instead of conforming to the values of organization, this individual is driven by his or her own values and beliefs, and sees an organization as a place where he or she can express his or her own values.

Given the importance of embracing protean and boundaryless career attitudes within today's organizational context and the fact that there are few studies in Spain centred on these new career perspectives, the aim of the present study is to translate the original scales into Spanish; examine the factor structure of protean and boundaryless career scales in a sample of professionals attending distancelearning courses.

\section{Translation of the scale}

The original scales developed in English were translated into Spanish, following a back-translation procedure (Nunnally \& Bernstein, 1994) to ensure the accuracy of the translation. In this procedure, a bilingual native Spanish person translates the scale from its original language to the language under study. Another bilingual native English individual, who is unfamiliar with the original scale, re-translates this version back to the original language. Afterwards, the two versions are compared in order to verify whether the meaning is the same and make the necessary corrections to the terminology.

Moreover, five cognitive interviews were conducted in order to ensure an accurate interpretation of the questionnaire items, as this technique allows understanding how respondents perceive and interpret questions, and to identify potential problems that may arise in prospective survey questionnaires (Drennan, 2003). Cognitive interviews permitted us interpreting which items are beyond the theoretical framework of the constructs to be analyzed (Collins, 2003; Jobe \& Mingay, 1989). By means of verbal probing and thinking aloud (Drennan, 2003; Williamson, Ranyard \& Cuthbert, 2000) participants are asked to verbalize their interpretation of items and to paraphrase and/or comment on the wording of items in an effort to identify ambiguous or poorly worded questions. Once collected the data, they were processed following Miles and Huberman (1994)'s suggestions. More specifically, the interviewees were asked to comment on the clarity and readability of the each item by asserting why they assessed it with a certain punctuation, and which parts of the items they found difficult to answer or interpret. Based on their comments minor stylistic and semantic changes were 
made. The Spanish translation of the protean and boundaryless career attitudes scales is illustrated in Table 1:

\begin{tabular}{|c|c|}
\hline SD1 & $\begin{array}{l}\text { Cuando mi empresa no me ha ofrecido oportunidades de desarrollo las he buscado yo } \\
\text { mismo/a }\end{array}$ \\
\hline SD2 & Soy responsable del éxito o del fracaso de mi carrera profesional \\
\hline SD3 & En general mi carrera profesional me la auto-dirijo de manera muy independiente \\
\hline SD4 & $\begin{array}{l}\text { La libertad de elegir mi propia trayectoria profesional es uno de los valores más } \\
\text { importantes para mi }\end{array}$ \\
\hline SD5 & Me responsabilizo de mi propia carrera profesional \\
\hline SD6 & En última instancia dependo de mí mismo/a para avanzar en mi carrera profesional \\
\hline SD7 & $\begin{array}{l}\text { En lo que se refiere a mi carrera profesional, soy una persona que se ha hecho(/se hace) } \\
\text { a si misma }\end{array}$ \\
\hline SD8 & $\begin{array}{l}\text { En el pasado, cuando ha sido necesario encontrar un nuevo trabajo, me he basado más } \\
\text { en mí mismo que en otras personas }\end{array}$ \\
\hline VD9 & $\begin{array}{l}\text { Gestiono mi propia carrera, basándome en mis propias prioridades personales, más que } \\
\text { en las prioridades fijadas por mis superiores }\end{array}$ \\
\hline VD10 & $\begin{array}{l}\text { No me importa mucho como otros evalúan mis decisiones respecto a mi carrera } \\
\text { profesional }\end{array}$ \\
\hline VD11 & $\begin{array}{l}\text { Sobre mi éxito profesional, para mí es más importante lo que opino yo, que lo que } \\
\text { puedan opinar los otros }\end{array}$ \\
\hline VD12 & $\begin{array}{l}\text { Si la empresa me pide hacer algo que va en contra de mis valores, me guiaré según mi } \\
\text { conciencia }\end{array}$ \\
\hline VD13 & $\begin{array}{l}\text { Lo que yo pienso que es bueno para mi carrera profesional es más importante que lo que } \\
\text { piense mi empresa }\end{array}$ \\
\hline VD14 & $\begin{array}{l}\text { En el pasado, permanecí fiel a mis propios valores cuando la empresa me pidió hacer } \\
\text { algo que no estaba de acuerdo }\end{array}$ \\
\hline BM15 & Busco tareas en el trabajo que me permitan aprender algo nuevo \\
\hline BM16 & Me gustaría trabajar en proyectos con personas de diferentes organ \\
\hline BM17 & Disfruto de realizar tareas que requieran trabajar fuera de mi organización \\
\hline BM18 & Me gustan las tareas que requieren trabajar con personas más allá de mi departamento \\
\hline BM19 & Disfruto trabajando con personas de otras organizaciones \\
\hline BM20 & $\begin{array}{l}\text { Disfruto con los trabajos que requieren que interactúe con personas de distintas } \\
\text { organizaciones }\end{array}$ \\
\hline BM21 & $\begin{array}{l}\text { En el pasado he buscado oportunidades laborales que me permitieran trabajar fuera de } \\
\text { la organización }\end{array}$ \\
\hline BM22 & Me entusiasman nuevas experiencias y situaciones \\
\hline OMP23 & Me gusta la previsibilidad que se deriva de trabajar en la misma organización \\
\hline OMP24 & Me sentiría muy perdido/a si no pudiera continuar trabajando en mi organización actual \\
\hline OMP25 & $\begin{array}{l}\text { Prefiero estar en una empresa con la que estoy familiarizado, que buscar empleo en } \\
\text { cualquier otro sitio }\end{array}$ \\
\hline OMP26 & $\begin{array}{l}\text { Si mi empresa me ofreciera seguridad laboral para toda la vida nunca desearía buscar } \\
\text { trabajo en otra organización }\end{array}$ \\
\hline OMP27 & Para mí, una carrera profesional ideal sería poder trabajar en una única organización \\
\hline
\end{tabular}

Table 1. Spanish version of the protean and boundaryless career attitudes scales

The next step consisted in performing a psychometric study of the Spanish version of protean and boundaryless career attitudes scales, using a sample of professionals attending distance-learning courses.

\section{Psychometric properties of the Spanish version of protean and boundaryless career attitudes scale}

\section{Participants}

Research data were collected using a web-based survey. The questionnaire was sent to 434 graduate and post-graduate distance learning students and after 2 weeks 167 surveys were submitted by the respondents, representing a response 
rate of $38.48 \%$. After handling the missing data, 150 usable entries had been obtained.

The respondents ( $58 \%$ women and $42 \%$ men) were anonymous and they should have been working, as the questionnaire items were related to their current employment experience. The average age of the respondents was 30.95 years old $(S D=7.46)$. Regarding the organizational size, most of them $(42.67 \%)$ were working for small companies, whereas a significant percentage (44\%) were employees of large companies and only a $13.34 \%$ were working in middle size companies. The average professional experience was 9.91 years $(S D=6.86)$, with an average organizational tenure of 5.25 years $(S D=5.44)$. The study's respondents represented a diverse set of industry sectors, such as: agriculture (2\%), industry $(26 \%)$, building $(9 \%)$ and service $(63 \%)$. The highest level of education completed was a PhD (5.33\%), while a $40 \%$ had completed a Bachelor's degree or a superior degree in engineering. The majority of the respondents (54.67\%) had completed pre-university studies, and they have enrolled in distance-learning education to get university degree.

\section{Methodology and results}

\section{Dimensionality of the scale}

As an initial step, we performed exploratory factor analysis to examine the factorstructure of the protean and boundaryless career attitudes scales. Kaiser-MyerOlkin statistic $(\mathrm{KMO}=0.736$ for the protean career attitudes scale, and $\mathrm{KMO}$ $=0.835$ for the boundaryless career attitudes scale) indicated that the correlation matrices were suitable for factor analysis. A principal component extraction was used, after which the number of factors was determined by the number of eigenvalues greater than one. This criterion suggested a four-factor solution (eigenvalues $3.91,2.048,1.304$ and 1.018) for the protean career attitudes scale and a three-factor solution for the boundaryless career attitudes scale (eigenvalues $=4.69,2.148$ and 1.077).

The first four unrotated factors together accounted for $59.14 \%$ of the total item variance of the protean career attitudes scale. In the case of the boundaryless career attitudes scale, the first three factors accounted for $60.88 \%$ of the total variance. Principal component analyses with varimax rotation are presented Table 2. 


\begin{tabular}{|c|c|c|c|c|c|c|c|c|}
\hline \multirow[b]{3}{*}{ SD01 } & \multicolumn{4}{|c|}{ FACTOR } & \multicolumn{4}{|c|}{ FACTOR } \\
\hline & 1 & 2 & 3 & 4 & & 1 & 2 & 3 \\
\hline & 0.311 & -0.001 & 0.133 & $\underline{0.646}$ & BM15 & 0.507 & -0.047 & -0.361 \\
\hline SD02 & $\underline{0.676}$ & -0.111 & -0.043 & $\overline{0.117}$ & BM16 & $\underline{0.775}$ & -0.157 & 0.027 \\
\hline SD03 & $\underline{0.672}$ & 0.045 & -0.056 & 0.226 & BM17 & $\underline{0.737}$ & 0.078 & 0.363 \\
\hline SD04 & $\overline{0.597}$ & 0.237 & 0.320 & -0.086 & BM18 & 0.829 & 0.128 & 0.087 \\
\hline SD05 & $\underline{0.777}$ & -0.018 & 0.138 & 0.186 & BM19 & $\underline{0.878}$ & 0.077 & 0.202 \\
\hline SD06 & 0.538 & 0.228 & -0.100 & 0.158 & BM20 & $\underline{0.860}$ & 0.128 & 0.168 \\
\hline SD07 & 0.173 & 0.071 & 0.022 & $\underline{0.825}$ & BM21 & 0.299 & -0.021 & 0.533 \\
\hline SD08 & 0.067 & 0.342 & 0.254 & 0.521 & BM22 & 0.473 & 0.029 & 0.455 \\
\hline SD09 & 0.431 & 0.523 & 0.220 & 0.075 & OMP23 & 0.086 & 0.379 & 0.412 \\
\hline VD10 & 0.052 & $\underline{0.821}$ & 0.025 & 0.031 & OMP24 & 0.178 & $\underline{0.663}$ & -0.011 \\
\hline VD11 & -0.068 & 0.871 & 0.081 & 0.085 & OMP25 & -0.001 & 0.729 & 0.059 \\
\hline VD12 & 0.066 & 0.163 & $\underline{0.862}$ & 0.043 & OMP26 & 0.023 & $\underline{0.841}$ & 0.059 \\
\hline VD13 & 0.145 & 0.563 & $\overline{0.415}$ & 0.188 & OMP27 & 0.185 & $\underline{0.780}$ & 0.132 \\
\hline VD14 & -0.050 & 0.076 & $\underline{0.829}$ & 0.202 & & & & \\
\hline
\end{tabular}

Table 2. Component matrix of the protean and boundaryless career attitudes scale

In factorial analysis, the relationship of an item to the underlying construct is determined by the factor loading. The higher the loading, the more the item is a pure measure of the factor. According to Comrey and Lee (1992), loadings of excess of 0.71 are considered excellent, 0.63 very good, 0.55 good, 0.45 fair, and 0.32 good. In the light of this consideration, we selected items which had factor loads higher than 0.63 (see the underlined items, in Table 2). Furthermore, the measure of statistical adequacy (MSA) i.e. the Kaiser-Meyer-Olkin statistic $(K M O=0.747)$, reveals that the research lends itself to factor analysis. Thus, the selected items of protean and boundaryless career attitudes scales with high factor loadings (SD01, SD02, SD03, SD05, SD07, VD10, VD11, VD12, VD14, BM16, BM17, BM19, BM20, OMP24, OMP25, OMP26 and OMP27) were factor analysed using principal component analysis and varimax rotation.

With regard to protean career attitudes we observe that after performing principal component extraction selecting the number of factors with eigenvalues greather than one, a three factor solution emerged. All the self-directed selected items charged into factor 1 , while values-driven selected items charged into two factors, suggesting that the values driven scale measures two latent traits: items VD 10 and VD11 seem to measure strong beliefs that guide individual behaviour, while items V12 and V13 seem to indicate strong beliefs when organizational and personal values do not match, that is reliance upon one's personal values and beliefs when the organization requires the individual to do something he or she deem to be wrong by their own standards (see Table 3 ).

As far as boundaryless career attitudes were concerned, factor analysis conducted with the modified scales suggested a two factor solution (after extracting as factors asi eigenvalues greater than one), suggesting the bi-dimensional nature of this 
scale: we observe that boundaryless mindset items charge into factor 1 , while organizational mobility preference factors charged into factor 2 (See table 4).

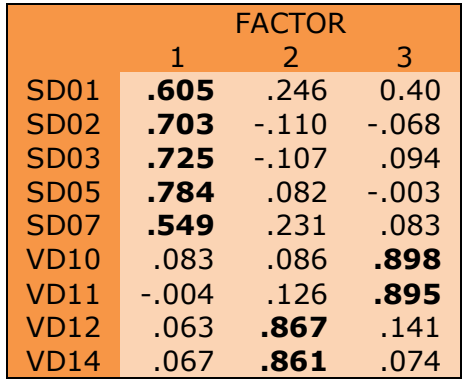

Table 3. Component matrix of the modified protean career attitudes scale

\begin{tabular}{|ccc|}
\hline & \multicolumn{2}{c|}{ FACTOR } \\
BM16 & $\mathbf{. 7 5 1}$ & .154 \\
BM17 & $\mathbf{. 8 1 3}$ & .101 \\
BM18 & $\mathbf{. 8 4 0}$ & .108 \\
BM19 & $\mathbf{. 9 2 5}$ & .074 \\
BM20 & $\mathbf{. 9 0 3}$ & .114 \\
OMP24 & .168 & $\mathbf{. 6 3 6}$ \\
OMP25 & .003 & $\mathbf{. 7 3 7}$ \\
OMP26 & .029 & $\mathbf{. 8 6 3}$ \\
OMP27 & .227 & $\mathbf{. 8 0 3}$ \\
\hline
\end{tabular}

Table 4. Component matrix of the modified boundaryless career attitudes scale

We conducted a confirmatory factor analysis (CFA) with AMOS to test the bidimensional structure of protean and boundaryless career attitudes scales. The tested models are reflected in Figure 1 and Figure 2. With regard to protean attitudes, results indicate that the three factor model fitted our data reasonably well $\left(X^{2}=36.2, \quad d f=24 ; \quad R M S E A=.05, \quad C F I=.956, \quad T L I=.934\right)$ Both the one-factor measurement model of protean career attitudes: $\left(X^{2}=180.3, d f=27 ; \operatorname{RMSEA}=.20\right.$, $\mathrm{CFI}=.445, \mathrm{TLI}=.261)$ and the two-factor model did not fit our data $\left(X^{2}=94.6\right.$, $\mathrm{df}=26$; RMSEA $=.13, \mathrm{CFI}=.752, \mathrm{TLI}=.656)$.
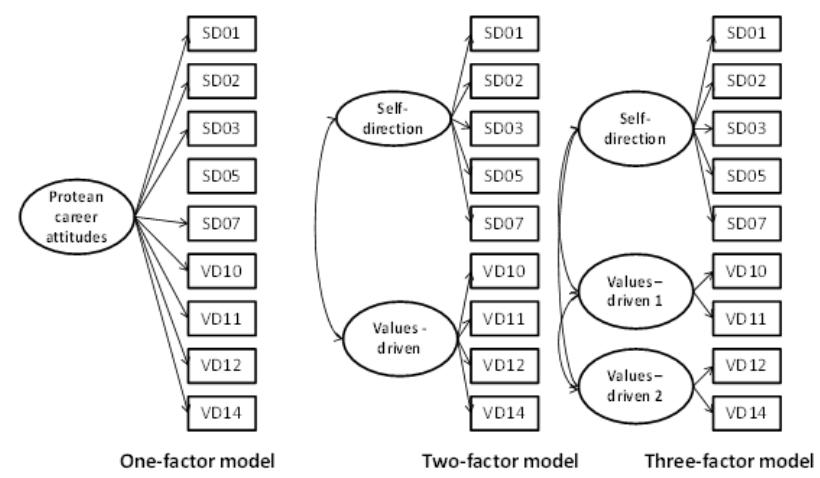

Figure 1. Comparison of the three models of protean career attitudes 
Subsequently, we performed a CFA to test the two-factor model of boundaryless career attitudes and the results show that the fit indexes fell within an acceptable range $\left(X^{2}=41, d f=26, \operatorname{RMSEA}=.06, \mathrm{CFI}=.979, \mathrm{TLI}=.971\right)$. The competing one factor measurement model did not fit our data $\left(X^{2}=192.8, d f=27\right.$; RMSEA $=.21, \mathrm{CFI}=.767$, TLI $=.690)$.

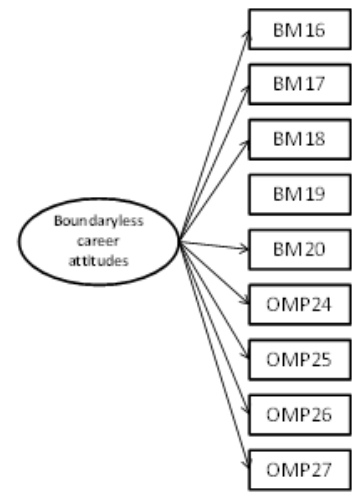

One-factor model

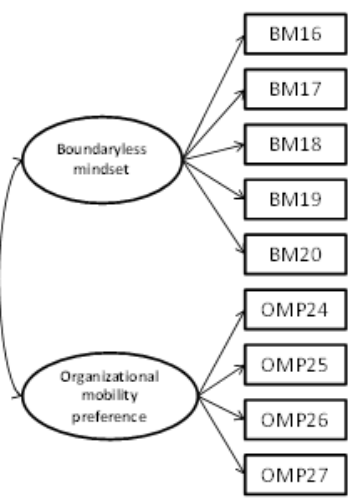

Two-factor model

Figure 2. Comparison of the two models of boundaryless career attitudes

\section{$\underline{\text { Reliability analyses }}$}

Reliability analyses were performed to determine if the study items formed homogeneous scales as would be supported by significant inter-item and item-total correlations, and internal consistency reliabilities as measured by Cronbach's alpha coefficient. The reliability analysis yielded alpha coefficients higher than 0.70 , excepting one construct (values-driven predispositions) that reported an a coefficient of 0.677. In addition, the item analyses through the scale if item eliminated procedure, the reliability indexes for the instrument and each scale remained stable (see Table 5, a coefficient for $S D=0.706$ ). This is indicative of high intercorrelations amongst the items that form the scales, allowing for the documentation that the instrument and its scales are reliable for the measurement of the underlying constructs proposed by Briscoe et al. (2006).

With respect to boundaryless career attitudes, both dimensions, organizational mobility preference $(a=0.770)$ and boundaryless mindset $(a=0.907)$, produced acceptable alpha coefficients, higher than .70 (Nunnally, 1978; Nunnally \& Bernstein, 1994), which indicates that the items in the scales are internally consistent with one another and that the scales are a sufficiently reliable measure of a construct (see Table 6). 


\begin{tabular}{|c|c|c|c|c|c|}
\hline Items & $\begin{array}{l}\text { Scale Mean if } \\
\text { Item Deleted }\end{array}$ & $\begin{array}{l}\text { Scale Variance if } \\
\text { Item Deleted }\end{array}$ & $\begin{array}{l}\text { Corrected Item- } \\
\text { Total Correlation }\end{array}$ & $\begin{array}{c}\text { Multiple Squared } \\
\text { Correlation }\end{array}$ & $\begin{array}{l}\text { Alfa Cronbach if } \\
\text { Item Deleted }\end{array}$ \\
\hline SD01 & 16.23 & 5.187 & .443 & .223 & .666 \\
\hline SD02 & 16.32 & 5.347 & .439 & .278 & .667 \\
\hline SD03 & 16.63 & 5.283 & .481 & .262 & .649 \\
\hline SD05 & 16.11 & 5.175 & .572 & .373 & .615 \\
\hline SD07 & 16.36 & 5.534 & .387 & .222 & .687 \\
\hline VD10 & 11.09 & 4.823 & .459 & .421 & .592 \\
\hline VD11 & 10.83 & 4.829 & .472 & .419 & .583 \\
\hline VD12 & 10.35 & 5.022 & .459 & .368 & .593 \\
\hline VD14 & 10.69 & 5.103 & .401 & .354 & .631 \\
\hline
\end{tabular}

Table 5. Reliability analysis of the protean career attitudes scale (Item-total statistics)

\begin{tabular}{|lrrrrr|}
\hline Items & $\begin{array}{r}\text { Scale Mean if } \\
\text { Item Deleted }\end{array}$ & $\begin{array}{c}\text { Scale Variance } \\
\text { if Item Deleted }\end{array}$ & $\begin{array}{c}\text { Corrected Item- } \\
\text { Total Correlation }\end{array}$ & $\begin{array}{c}\text { Multiple Squared } \\
\text { Correlation }\end{array}$ & $\begin{array}{c}\text { Alfa Cronbach if } \\
\text { Item Deleted }\end{array}$ \\
BM16 & 15.73 & 8.723 & .655 & .440 & .905 \\
BM17 & 16.20 & 7.960 & .720 & .541 & .897 \\
BM18 & 15.89 & 7.994 & .754 & .578 & .889 \\
BM19 & 16.03 & 7.643 & .869 & .818 & .864 \\
BM20 & 15.99 & 7.980 & .843 & .792 & .871 \\
& Scale Mean if & Scale Variance & Corrected Item- & Multiple Squared & Alfa Cronbach if \\
Items & Item Deleted & if Item Deleted & Total Correlation & Correlation & Item Deleted \\
OMP24 & 10.46 & 6.975 & .453 & .225 & .773 \\
OMP25 & 11.11 & 6.356 & .519 & .274 & .743 \\
OMP26 & 10.67 & 5.805 & .682 & .531 & .653 \\
OMP27 & 10.49 & 6.064 & .640 & .506 & .678 \\
\hline
\end{tabular}

Table 6. Reliability analysis of the boundaryless career attitudes scale (Item-total statistics)

\section{Discussion and conclusions}

The aim of this study was to offer a Spanish translation of Briscoe et al. (2006)'s protean and boundaryless attitudes scale and to analyse its internal psychometric properties. After performing exploratory factorial analysis we propose a revised version of the scale, which considers those items with a higher factor loading and suggests that the values driven attitudes scales is likely to measure two latent traits, underlying a bi-dimensional construct that emphases strong core beliefs regarding one's definition of career success and strong core beliefs that individuals use to guide their behaviour when individual and organizational values do not match. These results are consistent with De Bruin and Buchner (2010) recent findings.

The reliability analysis conducted with the revised scale of boundaryless and protean career attitudes provides general support to Briscoe et al. (2006)'s reported coefficients. For example, the self-directed attitudes scale revealed a smaller consistency (0.706) than that obtained by Briscoe et al. (2006) (0.810), 
while the reliability of the values-driven scale (0.670) was similar to that reported by Briscoe et al. (2006).

Another aspect to highlight refers to the number of void items that were eliminated from the sample. Analysing the cases considered invalid, we noticed that respondents left unanswered certain items included in the protean career attitudes scale. One of those items was the following: "In the past I have sided with my own values when the company has asked me to do something I don't agree with", making reference to a past situation and assuming that the respondent had already experienced this kind of organizational demand. We believe that those who left unanswered this item might not have lived such labour situation in their employing organization. Moreover, we doubt in discerning whether there are many, few or no respondents who, in spite of not having experienced such a situation, have marked the Likert scale associated to this item and this fact might have partially distorted the results and internal consistencies. This particular item was not included in the revised version of the scale, as factor analysis performed with varimax rotation presented a low factor loading for this specific item. Similarly some respondents left unanswered the item "When development opportunities have not been offered by my company, I've sought them out on my own", which also makes reference to a past situation, suggesting that these respondents might have lacked a clear circumstantial reference for it.

When analysing the values driven items that were selected after factor analysis, it can be noticed that the four remaining make reference on the one hand at one's reliance upon a personal definition of career success ("It doesn't matter much to me how others evaluate the choices I make in my career" and "What's most important to me is how I feel about my career success, not how other people feel about it") and, on the other hand, individuals' emphasis upon personal values through work ("I'll follow my own conscience if my company asks me to do something that goes against my values" and "In the past, I have sided with my own values when the company has asked me to do something I don't agree with"). In fact, these two items are associated with individuals' perceptions when faced with a low values-fit with their employing organization.

On the other hand, the analysis of the boundaryless career attitude scales revealed higher internal consistencies than the protean one, and did not generally raised problems regarding specific items. Both dimensions, organizational mobility preference $(a=0.770)$ and boundaryless mindset $(a=0.907)$, yielded to similar 
internal consistencies as those reported by Briscoe et al. (2006) (namely 0.75 and 0.89 respectively).

There are several limitations associated with the present study. One limitation refers to the relatively small sample size. It has been argued that confirmatory analyses should be conducted on samples larger than 100 (Gorsuch, 1983). Our sample size meets this requirement, but future research drawing on larger samples is encouraged as the precision of the covariance matrix increases (Quintana \& Maxwell, 1999). Another limitation refers to the characteristics of the sample, as respondents were relatively homogeneous in terms of age and educational background. However, we have focused this study on individuals who were pursuing enhancing their current competences and skills thorough distance-learning education in order to count on professionals with a certain proactive attitude which is required for embracing protean and boundaryless careers. Finally, future research drawing on this revised Spanish version of the scale is encouraged in order to further validate it on lager samples and in distinct cultural context within the Spanish-speaking population.

\section{References}

ARTHUR, M.B. (1994). The boundaryless career - a new perspective for organizational inquiry. Journal of Organizational Behavior, 15(4): 295-306.

ARTHUR, M.B.; ROUSSEAU, D.M. (1996). The boundaryless career: A new employment principle for a new organizational era. New York: Oxford University Press.

BARUCH, Y. (2004). Managing careers: Theory and practice. Harlow, UK: Prentice Hall.

BELL, N.E.; STAW, B.M. (1989). People as sculptors vs. sculpture: The role of personality and personal control in organizations. In M.B. Arthur, D.T. Hall, \& B.S. Lawrence (Eds.), Handbook of career theory. Cambridge: Cambridge University Press.

BRISCOE, J.P.; HALL, D.T.; DEMUTH, R.L.F. (2006). Protean and boundaryless careers: An empirical exploration. Journal of Vocational Behavior, 69(1): 30-47. http://dx.doi.org/10.1016/j.jvb.2005.09.003 
BRISCOE, J.P.; FINKELSTEIN, L. (2009). The "new career" and organizational commitment: Do boundaryless and protean attitudes make a difference?. Career Development International, 14(3): 242-260. http://dx.doi.org/10.1108/13620430910966424

CAPPELLI, P. (1999). Career jobs are dead. California Management Review, 42(1): 146-167.

COLLINS, D. (2003). Pretesting survey instruments: An overview of cognitive methods. Quality of Life Research, 12(3), 229-238. http://dx.doi.org/10.1023/A:1023254226592

COMREY, A.L.; LEE, H.B. (1992). A first course in factor analysis (2 ${ }^{\text {nd }}$ Eds.). Hillsdale, NJ: Erlbaum.

DE BRUIN, G.P.; BUCHNER, M. (2010). Factor and item response theory analysis of the protean and boundaryless career attitude scales. SA Journal of Indistrial Psychology/SA Tydskrif vir Bedryfsielkunde, 36(2): 1-11.

DEFILLIPPI, R.J.; ARTHUR, M.B. (1994). The boundaryless career - A competencebased perspective. Journal of Organizational Behavior, 15(4): 307-324. http://dx.doi.org/10.1002/job.4030150403

DRENNAN, J. (2003). Cognitive interviewing: Verbal data in the design and pretesting of questionnaires. Journal of Advanced Nursing, 42(1): 57-63. http://dx.doi.org/10.1046/j.1365-2648.2003.02579.x

ENACHE, M.; SALLAN, J.M.; SIMO, P.; FERNANDEZ, V. (2011). Examining the impact of protean and boundaryless career attitudes upon subjective career success. Journal of management and organization, 17(4): 460-474. http://dx.doi.org/10.5172/jmo.2011.17.4.459

FELDMAN, D.C.; NG, T.W.H. (2007). Careers: Mobility, embeddedness, and success. Journal of Management, 333(3): 350-377. http://dx.doi.org/10.1177/0149206307300815

FERNANDEZ, V.; ENACHE, M. (2008). Exploring the relationship between protean and boundaryless career attitudes and affective commitment through the lens of a fuzzy-set QCA methodology. Intangible Capital, 4(1): 31-66.

GORSUCH, R.L. (1983). Factor analysis (2 ${ }^{\text {nd }}$ Eds.). Hillsdale, NJ: Erlbaum. 
GRATTON, L.; GHOSHAL, S. (2003). Managing Personal Human Capital: New Ethos for the 'Volunteer' Employee. European Management Journal, 21(1): 1-10.

HALL, D.T. (1976). Careers in organizations. Thousand Oaks: CA: Sage.

HALL, D.T. (2002). Protean careers in and out of organizations. Thousand Oaks: CA: Sage.

HALL, D.T. (2004). The protean career: A quarter-century journey. Journal of Vocational Behavior, 65(1): 1-13. http://dx.doi.org/10.1016/j.jvb.2003.10.006

HALL, D.T.; CHANDLER, D.E. (2005). Psychological success: When the career is a calling. Journal of Organizational Behavior, 26(2): 155-176. http://dx.doi.org/10.1002/job.301

JOBE, J.B.; MINGAY, D.J. (1989). Cognitive research improves questionnaires. American Journal of Public Health, 79(8): 1053-1055. http://dx.doi.org/10.2105/AJPH.79.8.1053

JONES, C. (1996). Careers in project networks: The case of the film industry. In M.B. Arthur, \& D.M. Rousseau (Eds.). The boundaryless career: 58-75. New York: Oxford University Press.

MCARDLE, S.; WATERS, L.; BRISCOE, J.P.; HALL, D.T. (2007). Employability during unemployment: Adaptability, career identity and human and social capital. Journal of Vocational Behavior, 71(2): 247-264. http://dx.doi.org/10.1016/j.jvb.2007.06.003

MILES, M.B.; HUBERMAN, A. (1994). Qualitative data analysis: An expanded sourcebook. Newbury Park. CA: Sage Publications.

NUNNALLY, J.C. (1978). Psychometric Theory (2 ${ }^{\text {nd }}$ Eds.). New York: McGraw Hill. NUNNALLY, J.C.; BERNSTEIN, I.H. (1994). Psychometric Theory (3 ${ }^{\text {rd }}$ Eds). New York: McGraw Hill.

PEEL, S.; INKSON, K. (2004). Contracting and careers: Choosing between self and organizational employment. Career Development International, 9(6): 542-558. http://dx.doi.org/10.1108/13620430410559142

POWELL, W.W.; SNELLMAN, K. (2004). The knowledge economy. Annual Review of Sociology, 30: 199-220. http://dx.doi.org/10.1146/annurev.soc.29.010202.100037 
QUINTANA, S.M.; MAXWELL, S.E. (1999). Implications of recent developments of structural equations modeling to counseling psychology. The Counselling Psychologist, 27(4): 485-527. http://dx.doi.org/10.1177/0011000099274002

ROUSSEAU, D.M. (1989). Psychological and implied contracts in organizations. Employee Responsibilities and Rights Journal, 2(2): 121-139. http://dx.doi.org/10.1007/BF01384942

SAXENIAN, A.L. (1996). Beyond boundaries: Open labor markets and learning in Silicon Valley. In M.B. Arthur, \& D.M. Rousseau (Eds.), The boundaryless career: 23-39. New York: Oxford University Press.

SULLIVAN, S.E. (1999). The changing nature of careers: A review and research agenda. Journal of Management, 25(3): 457-484.

SULLIVAN, S.E.; ARTHUR, M.B. (2006). The evolution of the boundaryless career concept: Examining physical and psychological mobility. Journal of Vocational Behavior, 69(1): 19-29. http://dx.doi.org/10.1016/j.jvb.2005.09.001

WEICK, K.E. (1996). Enactment and the boundaryless career: Organizing as we work. In M.B. Arthur, \& D.M. Rousseau (Eds.). The boundaryless career: A new employment principle for a new organizational era: 40-57. New York: Oxford University Press.

WILLIAMSON, J.; RANYARD, R.; CUTHBERT, L. (2000). A conversation-based process tracing method for use with naturalistic decisions: An evaluation study. British Journal of Psychology, 91: 203-221. http://dx.doi.org/10.1348/000712600161790

Intangible Capital, 2012 (www.intangiblecapital.org)

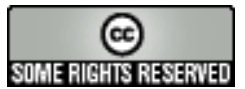

Article's contents are provided on a Attribution-Non Commercial 3.0 Creative commons license. Readers are allowed to copy, distribute and communicate article's contents, provided the author's and Intangible Capital journal's names are included. It must not be used for commercial purposes. To see the complete licence contents, please visit http://creativecommons.org/licenses/by-nc/3.0/es/ 